\title{
The Effects of Gibberellic Acid (GA3) Applications on the Physiological Features of Groundnut (Arachis hypogaea L.) under Different Salt (NaCI) Stress Conditions
}

\begin{abstract}
Background: Salinity is one of the most imperative problems of farmers worldwide. Reports are available that the external application of GA3 can reduce harmful effects of salinity. Low concentration and small quantities of GA3, a phytohormone, is essential to hasten the growth and development of plants. The current study was aimed to test the efficiency of GA3 on the impart of salt tolerance in terms of better nutrient uptake under salt stress situation and to determine the effect of external giberellic acid applications on the physiological properties and proline level of peanuts under different salt $(\mathrm{NaCl})$ stress conditions on the degree of resistance to salt stress in peanuts.

Methods: Trial was established as split plot design with 3 replications and NC-7 variety was used as a material. The chlorophyll content in leaves, ion ( $\mathrm{K}, \mathrm{Na}, \mathrm{Mg}, \mathrm{Ca})$ content, cell membrane permeability were searched in the research. To determine the physiological responses of groundnut in the conditions of Gibberellic asid (GA3), $(0,5,15 \mathrm{mM})$ applications under the different salt (Nacl), $(0,25$, $50,100 \mathrm{mM}$ ) stress conditions at the plant growth room in the GAP Agricultural Research Institute in Şanlıurfa, Turkey in 2019. The chlorophyll content in leaves, ion ( $\mathrm{K}, \mathrm{Na}, \mathrm{Mg}, \mathrm{Ca}$ ) content, cell membrane permeability were searched in the research.

Result: The increasing salt applications decreases the leaf chlorophyll content and leaf ions $(\mathrm{K}, \mathrm{Mg}, \mathrm{Ca})$ content, in contrast, increased the cell membrane permeability, proline content and sodium concentration were determined. The gibberallic asid applied externally against salt stress were determined to have the positive effects on traits; leaf chlorophyll content, ion $(\mathrm{K}, \mathrm{Na}, \mathrm{Mg}$, Ca) content, cell membrane permeability, proline content.
\end{abstract}

Key words: Chlorophyll content, Gibberellic asid, Groundnut, Proline, Salt.

\section{INTRODUCTION}

Groundnut (Arachis hypogaea L.), also known as peanut, earthnut is a self-pollinating, indeterminate, annual herbaceous crop and belongs to the family Leguminoceae Adinya et al. (2010). Groundnut, whose fatherland is South America outshines with its several aspects at agricultural field. A legume plant as green feed directly to humans and animals as it is fed, dried and made into bales. It is used as animal food in winter season. Groundnut is one of the five greatly cultivated oil seed crops in Turkey (FAO, 2019). Southeastern Anatolia Project (SAP) region in Turkey retains varying climatic conditions results in the cultivation of a wide range oil crops such as groundnut. These rural areas are exposed to salts under several levels and compositions.

The all cultivated crops do not exhibit same reaction against salinity. While the some plants more susceptible to salinity, some plants are more resistant. Groundnut has been recognized the plant as a moderately sensitive to salinity Mensah et al. (2006). Excessive amount of $\mathrm{Na}$ contained in the plant cytoplasm shows toxic effect by blocking the enzyme activity and protein synthesis. In contrast, it is known that the greater chlorine rate collected in the tissues much than sodium affects the photosynthesis and therefore product adversely due to causes damages in the leaves. The accumulation of organic compounds such as saccharose, proline, gibberallic acid (GA3), betaine as
Department of Field Crops, Gundas Research Station, R. Tayyip Erdogan Bul. No: 106, Haliliye, Sanliurfa, Turkey.

Corresponding Author: E. Erbil, GAP Agricultural Research Institute, 63109-Sanliurfa, Turkey. Email: erdal_erbil@hotmail.com

How to cite this article: Erbil, E. (2021). The Effects of Gibberellic Acid (GA3) Applications on the Physiological Features of Groundnut (Arachis hypogaea L.) under Different Salt ( $\mathrm{NaCl})$ Stress Conditions. Legume Research. 44(10): 1159-1163. DOI: 10.18805/LR-620.

Submitted: $13-03-2021 \quad$ Accepted: 30-07-2021 Online: 21-08-2021

osmoprotectants the adverse effects of salinity in the plant cell Jiao et al. (2019).

Gibberellins commonly known as gibberellic acids first came to the attentionof western scientists in 1950s, Gibberellins (GAs) are endogenous plant growth regulators, having tetracyclic, diterpenoid compounds. After valuable efforts to understand the GA biosynthesis and movements, the appropriate site of bioactive GA in plants or tissues targeted by bioactive GAs to initiate their action has not yet been confirmed (Gupta and Chakrabarty 2013). Reports are available that the external application of GA3 can reduce harmful effects of salinity (Hayat et al. 2001; LeubnerMetzger 2003). Low concentration and small quantities of GA3, a phytohormone, is essential to hasten the growth and development of plants (Hassan and Ismail, 2018). 
Furthermore, for plants appropriate conditions may be created by applying a growth regulator gibberallic acid (GA3) at the correct concentration and at the stipulated time for a particular plant crop (Meera and Poonam, 2010).

With Increasing salinity, $\mathrm{Na}$ content increases $\mathrm{K}$ and Ca content decrease in groundnut leaves Ghosh et al. (2001). Groundnut species gives react differently to diferrent salt concentrations (Chauhan and Singh, 2000). Salt and drought stress have negative impacts on the growth of groundnut plant, organs, dry matter, soluble protein and chlorophyll content (Mensah et al. 2006; Teixeira and Pereira 2007). The proline that accumulates in plants balancing the osmotic pressure, effects of the concentrations such as; $\mathrm{Na}$, $\mathrm{K}, \mathrm{Mg}$ and $\mathrm{Ca}$ ions and reported to have an important place in strengthening of the cell wall, enzyme activities and chlorophyll molecules (Iba, 2002).

Researches have shown that, GA3 accumulation in different stress conditions is species-specific characters, even that carry differences between same species and the amounts of GA3 accumulation in plants varying due to stress conditions and possible to detect the resistant plants to salt stress by making use of resisting stress (Mohanty and Sahoo, 2000; Renugadevi and Vijayageetha 2006). GA3 is the most commonly used hormone or growth-regulating chemical under in the laboratory experiments.

It was aimed with this study to test the efficiency of GA3 on the impact of salt tolerance in terms of better nutrient uptake under salt stress situation and to determine the effect of external giberellic acid applications on the physiological properties and proline level of peanuts under different salt $(\mathrm{NaCl})$ stress conditions on the degree of resistance to salt stress in peanuts.

\section{MATERIALS AND METHODS}

NC-7 groundnut variety was used as a plant material in this study. Planting seeds which were subjected advent regerminate in 10 liter pots and as plant growth environment, sand-perlite mixture (1:1) was used. The plant growth ambient temperature in the room during the day / night fixed set of $22{ }^{\circ} \mathrm{C}$ and 10000 lux lighting, to be 16 hours daylight and 8 hours darkness, blue and red wavelengths are provided with highly fluorescent lamps (18 W osram flora/ 840).

The all plants were given $1 / 2$ Hoagland nutrient solution without any stress factor from the first 20 days of emergence. After this time, different concentrations of salt $(\mathrm{NaCl})$ were applied once a week for nine weeks at the groundnut plants which are selected randomly in the nutrient mediums. Salt concentrations of the $0,25,50,100 \mathrm{mM} \mathrm{NaCl}$ were applied to plants, $1 / 2$ Hoagland nutrient solution was used as solvent in the preparation of salt concentrations. The control plants were given the nutrient solution of $1 / 2$ Hogland only. After the salt stress treatment, 0,5 and $15 \mathrm{mM}$ of gibberallic acid (GA3) concentration in $500 \mathrm{ml}$ of distilled water were sprayed to the surface of the plant leaves.
The applications were performed as follows;

Control (Single nutrient solution),

Nutrient solution + $5 \mathrm{mM}$ Gibberallic acid,

Nutrient solution + $15 \mathrm{mM}$ Gibberallic acid,

Nutrient solution $+25 \mathrm{mM} \mathrm{NaCl}$,

Nutrient Solution $+50 \mathrm{mM} \mathrm{NaCl}$,

Nutrient solution $+100 \mathrm{mM} \mathrm{NaCl}$,

Nutrient solution $+5 \mathrm{mM}$ Gibberallic acid $+25 \mathrm{mM} \mathrm{NaCl}$,

Nutrient solution + $5 \mathrm{mM}$ Gibberallic acid $+50 \mathrm{mM} \mathrm{NaCl}$,

Nutrient solution + $5 \mathrm{mM}$ Gibberallic acid $+100 \mathrm{mM} \mathrm{NaCl}$,

Nutrient solution + $15 \mathrm{mM}$ Gibberallic acid $+25 \mathrm{mM} \mathrm{NaCl}$,

Nutrient solution + $15 \mathrm{mM}$ Gibberallic acid + $50 \mathrm{mM} \mathrm{NaCl}$,

Nutrient solution + $15 \mathrm{mM}$ Gibberallic acid + $100 \mathrm{mM} \mathrm{NaCl}$.

Trial was subjected to analysis of variance with regard to split-plot experimental design. The salt concentration consisted of the main plots, GA3 concentration were subplots in the experiment. JMP 13.0 statistical software package was used to determine the factors used such as the effects of salt and GA3 and their interaction in the experiment.

\section{Statistical analysis}

All the data obtained were analysed using the IBM Statistical Package for the Social Sciences (SPSS) version 22. Significant difference of mean values were determined and analysed using one-way ANOVA and the mean differences were compared using Duncan's multiple range test (DMRT) at $1 \%$ level of significance.

\section{RESULTS AND DISCUSSION}

The sodium level remained at the lowest level in plants at which the salt stress were not applied, the GA3 applied externally was not found to have a significant impact on the sodium content of groundnut leaves (Table 1). Sodium accumulation in plants is increased (Köşkeroğlu, 2006) by the breaks down of root membrane selectivity in saline environments. The evidences available show that, $\mathrm{Na}$ values are increased in many plants under salt stress (Özcan et al., 2000; Ghosh et al., 2001). Again, it has been reported by several researchers that, the applied GA3 to plants externally shows healing effects under salt stress (Gadallah, 1999; Hassan and Ismail, 2018).

Generally, K content in the leaves decreased significantly depends on the increased of the salt concentration. Reductions in the amount of potassium occurs in groundnut plants that grown in saline environments (Tıpırdamaz, 1989; Ghosh et al., 2001). Furthermore, the several researchers reported that, $\mathrm{K}$ content in the leaf increased by the application of GA3 to plants externally under salt stress Purohit et al. (2020). It was determined as a result of this study, the calcium content in the leaves vary between $0.64 \%$ between 0.51 , the highest calcium content in the control plants, the lowest calcium content in the application of 0 mM GA3 and $100 \mathrm{mM}$ salt. The amount of calcium was at the highest level in case of the salt stress not applied in plants and the adverse effects was determined in the calcium 
The Effects of Gibberellic Acid (GA3) Applications on the Physiological Features of Groundnut (Arachis hypogaea L.) under...

content of groundnut leaves by the application of GA3 externally.

$\mathrm{Na}$ to compete with other cationic elements especially in the element binding region of the membranes of plants under salt stress and evidences available about the reductions in transports and uptake of potassium, magnesium, calcium and some nutrients due to the disruption of electrolytes balance of intracellular. Verma et al. (2009) reported similar findings, in which Gibberallic acid (GA3) improved the yield of rice. Furthermore, it was reported that by several researchers, the content of $\mathrm{Ca}$ in the leaf is increased by the application of GA3 to plants externally under the salt stress.

When the control plants compared with 5 and $15 \mathrm{mM}$ of GA3 applied externally and the highest content of magnesium at the salt stress is not applied in plants, statistically in the control group, the GA3 was found to be the adverse effects on the content of magnesium. Generally, the magnesium content in the leaves decreased significantly in case of the salt concentration is increased. It might be concluded that, the amount of magnesium decreased because of the sodium replacing with the magnesium on the chlorophyll molecules in plants under salt stress.

The findings on the content of chlorophyll a in the leaves of NC-7 type groundnut plant that obtained by the applications of different salts and GA3 were presented in Table 2. The highest content of chlorophyll a occurs in plants in case of salt stress was not applied and different groups with control were formed by the applications of 5 and 15 mM GA3 externally, statistically, in the control group, the application of GA3 externally were found decreased the content of chlorophyll a. Generally, the content of chlorophyll a in leaves decreased significantly depending on the increasing salt concentration.
Different groups formed with the control by the applications of 5 and $15 \mathrm{mM} \mathrm{GA3}$ externally in case of the salt stress was not applied to plants, the application of 5 mM GA3 effected the content of chlorophyll b positively. Generally, the chlorophyll $b$ in the leaves varied in case of the salt concentration is increased. The evidence available is that, the chlorophyll $b$ in salt stress is varied according to the plant variety and genotype Khan et al. (2010). Furthermore, the applications of GA3 depending on the increasing salt stress increased the content of chlorophyll $b$ in leaf. Moneruzzaman et al. (2011) determined that, foliar application of GA3 increased leaf chlorophyll content of of the red jambu air madu fruits (Syzygium samarangense).

The lowest cell membrane permeability was from the control plants. Cell membrane permeability in the plants in which salt stress was not applied was the lowest and externally applications of 5 and 15 mM GA3 had been placed in the same group with the control group and statistically, in the control group, the application of GA3 externally has been found to have no impact on cell membrane permeability. Generally, in parallel with increasing salt concentration, the cell membrane permeability in the leaf increased significantly. Evidence is available that cell membrane permeability increase in the saline growth is due to the decrease of chlorophyll content (Flexas et al., 2004; Mafakheri et al., 2010. Binici, (2005) wheat; Köşkeroğlu, (2006), corn and Yakıt and Tuna (2006) have reported that salt stress in the corn plants increased cell membrane permeability. Furthermore, increasing applications of GA3 depending on salt stress decreased membrane permeability of the cells in the leaves significantly.

The lowest amount of GA3 in plants without salt stress and exogenously 5 and $15 \mathrm{mM} \mathrm{GA3}$ applications with control in different groups statistically, in the control group, exogenously Applied, GA3 has been extracted to increase

Table 1: Changes in some nutrient content in peanuts in response to salinity stress and externally applied GA3.

\begin{tabular}{|c|c|c|c|c|}
\hline Treatment & $\mathrm{Na}^{* *}(\%)$ & $\mathrm{K}^{* *}(\%)$ & $\mathrm{Ca}^{* *}(\%)$ & $\mathrm{Mg}^{* \star}(\%)$ \\
\hline Control & $0.42 \mathrm{~g}$ & $1.55 \mathrm{a}$ & $0.64 a$ & $0.27 a$ \\
\hline $\mathrm{NS}+5 \mathrm{mM} \mathrm{GA} 3$ & $0.41 \mathrm{~g}$ & $1.54 \mathrm{a}$ & $0.60 \mathrm{~b}$ & $0.25 a b$ \\
\hline $\mathrm{NS}+15 \mathrm{mM}$ GA3 & $0.43 \mathrm{~g}$ & $1.53 a$ & $0.61 b$ & $0.25 a b$ \\
\hline $\mathrm{NS}+25 \mathrm{mM} \mathrm{Nacl}$ & $0.91 \mathrm{e}$ & $1.46 c$ & $0.62 b$ & $0.22 \mathrm{bc}$ \\
\hline $\mathrm{NS}+50 \mathrm{mM} \mathrm{Nacl}$ & $1.59 c$ & $1.32 \mathrm{e}$ & $0.55 \mathrm{~cd}$ & $0.20 \mathrm{~cd}$ \\
\hline $\mathrm{NS}+100 \mathrm{mM} \mathrm{Nacl}$ & $1.99 a$ & $1.07 \mathrm{~g}$ & $0.51 \mathrm{e}$ & $0.18 d$ \\
\hline $\mathrm{NS}+5 \mathrm{mM} \mathrm{GA3+25} \mathrm{mM} \mathrm{Nacl}$ & $0.66 f$ & $1.52 \mathrm{ab}$ & $0.62 a b$ & $0.23 a b c$ \\
\hline $\mathrm{NS}+5 \mathrm{mM}$ GA3+50 mM Nacl & $0.91 \mathrm{e}$ & $1.41 d$ & $0.60 \mathrm{~b}$ & $0.23 a b c$ \\
\hline $\mathrm{NS}+5 \mathrm{mM} \mathrm{GA3+100} \mathrm{mM} \mathrm{Nacl}$ & $1.88 b$ & $1.17 f$ & $0.53 d$ & $0.18 d$ \\
\hline $\mathrm{NS}+15 \mathrm{mM} \mathrm{GA3}+25 \mathrm{mM} \mathrm{Nacl}$ & $0.61 f$ & $1.55 a$ & $0.62 a b$ & $0.26 a b$ \\
\hline $\mathrm{NS}+15 \mathrm{mM} \mathrm{GA3+50} \mathrm{mM} \mathrm{Nacl}$ & $0.84 \mathrm{e}$ & $1.47 \mathrm{bc}$ & $0.62 a b$ & $0.25 a b$ \\
\hline $\mathrm{NS}+15 \mathrm{mM}$ GA3+100 mM Nacl & $1.44 d$ & $1.39 d$ & $0.56 c$ & $0.22 \mathrm{bc}$ \\
\hline \multicolumn{5}{|l|}{ LSD } \\
\hline GA3 & 0.5 & 0.02 & 0.013 & 0.008 \\
\hline $\mathrm{Nacl}$ & 0.05 & 0.03 & 0.015 & 0.009 \\
\hline $\mathrm{GA}^{*}{ }^{*} \mathrm{Nacl}$ & 0.09 & 0.04 & 0.026 & 0.015 \\
\hline
\end{tabular}

Different letters in the same column are significantly different at ** $1 \%$ level (Duncan's multiple range test). 
The Effects of Gibberellic Acid (GA3) Applications on the Physiological Features of Groundnut (Arachis hypogaea L.) under...

Table 2: Changes in some physiological parameters in peanuts in response to salinity stress and externally applied GA3.

\begin{tabular}{|c|c|c|c|c|}
\hline Treatment & $\begin{array}{c}\text { Chlorophyll } a^{* *} \\
(\mathrm{mg} / \mathrm{g})\end{array}$ & $\begin{array}{c}\text { Chlorophyll } b^{* *} \\
(\mathrm{mg} / \mathrm{g})\end{array}$ & $\begin{array}{c}\text { Cell membrane } \\
\text { permeability** }(\%)\end{array}$ & $\begin{array}{c}\text { Proline }^{* *} \\
(\mu \mathrm{mol} / \mathrm{g} \text { fresh weight })\end{array}$ \\
\hline Control & $2.594 a$ & $0.361 f$ & $6.16 \mathrm{j}$ & $0.038 \mathrm{k}$ \\
\hline $\mathrm{NS}+5 \mathrm{mM}$ GA3 & $2.457 b$ & $0.545 d$ & $6.50 \mathrm{j}$ & $0.119 \mathrm{j}$ \\
\hline $\mathrm{NS}+15 \mathrm{mM}$ GA3 & $2.515 a b$ & $0.308 \mathrm{fg}$ & $6.50 \mathrm{j}$ & $0.203 ı$ \\
\hline $\mathrm{NS}+25 \mathrm{mM} \mathrm{Nacl}$ & $0.882 f$ & $0.593 d$ & $22.14 \mathrm{~g}$ & $0.224 \mathrm{~h}$ \\
\hline $\mathrm{NS}+50 \mathrm{mM} \mathrm{Nacl}$ & $0.707 \mathrm{~g}$ & $0.453 e$ & $52.77 \mathrm{c}$ & $0.292 f$ \\
\hline $\mathrm{NS}+100 \mathrm{mM} \mathrm{Nacl}$ & $0.644 \mathrm{~g}$ & $0.298 \mathrm{~g}$ & $69.42 a$ & $0.471 \mathrm{c}$ \\
\hline $\mathrm{NS}+5 \mathrm{mM} \mathrm{GA3+25} \mathrm{mM} \mathrm{Nacl}$ & $2.021 d$ & $1.284 a$ & $14.99 \mathrm{~h}$ & $0.253 \mathrm{~g}$ \\
\hline $\mathrm{NS}+5 \mathrm{mM} \mathrm{GA3+50} \mathrm{mM} \mathrm{Nacl}$ & $1.061 \mathrm{e}$ & $0.837 \mathrm{c}$ & $38.47 e$ & $0.339 \mathrm{e}$ \\
\hline 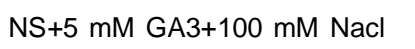 & $0.833 f$ & $0.218 \mathrm{~h}$ & $58.88 \mathrm{~b}$ & $0.631 b$ \\
\hline $\mathrm{NS}+15 \mathrm{mM} \mathrm{GA3+25} \mathrm{mM} \mathrm{Nacl}$ & $2.216 \mathrm{c}$ & $1.168 \mathrm{~b}$ & $11.61 ।$ & $0.281 f$ \\
\hline $\mathrm{NS}+15 \mathrm{mM} \mathrm{GA3+50} \mathrm{mM} \mathrm{Nacl}$ & $2.421 b$ & $1.233 a$ & $29.29 f$ & $0.374 d$ \\
\hline $\mathrm{NS}+15 \mathrm{mM} \mathrm{GA3}+100 \mathrm{mM} \mathrm{Nacl}$ & $2.015 d$ & $1.138 \mathrm{~b}$ & $43.13 d$ & $0.752 a$ \\
\hline \multicolumn{5}{|l|}{ LSD } \\
\hline GA3 & 0.05 & 0.03 & 1.41 & 0.008 \\
\hline $\mathrm{Nacl}$ & 0.05 & 0.03 & 0.015 & 0.009 \\
\hline $\mathrm{GA}^{*} \mathrm{Nacl}$ & 0.09 & 0.04 & $0, .026$ & 0.015 \\
\hline
\end{tabular}

Different letters in the same column are significantly different at ${ }^{*} 1 \%$ level (Duncan's multiple range test).

the amount of gibberallic acid. In general, the amount of proline in the leaf increased significantly due to the increasing salt concentration. Proline is one of the substances that arise under the effect of stress under salt stress in cultivated plants Durmus et al. (2017). Proline, an amino acid, is an osmoregulation that is secreted internally by the plant in order to prevent damage to cells and tissues, at least in the early stages, in plants under stress. As a matter of fact, our findings are consistent with Tatar (2006), which states that the accumulation of some inorganic ions or organic compounds with low molecular weight was observed by plants in order to balance the osmotic potential against the initial effects of salinity, which causes inhibition of water uptake by the roots due to high ion content in the soil solution. Our findings suggest that some researchers reported that the amount of proline in the plant increased due to increasing salt concentrations (Özcan et al., 2000; Öncel and Keleş 2002; Gehlot, 2005; Sayari et al., 2005; Knipp and Honermeier 2006; Yakıt and Tuna 2006; Koca, 2007).

\section{CONCLUSION}

It was determined that salt stress increased the cell membrane permeability, the amount of proline and the sodium concentration in leaves, while reducing the concentration of potassium, magnesium and calcium in the leaves. It was observed that application of salt together with GA3in the plants did not eliminate the adverse effects completely despite the growth retarder impact.

In research it was found that GA3 doses applied had no impact on the control plants and the $5 \mathrm{mM} \mathrm{GA3}$ application was found insufficient in application of $100 \mathrm{mM}$ salt. As the result of research, the applied of GA3 may help to determine selection of plants that can be grown in saline conditions. Research concluded economic analysis needs to be done and it was suitable to apply GA3 in increasing doses to groundnuts in the fields accordig to their salinity levels where groundnuts are to be grown.

\section{REFERENCES}

Adinya, I.B., Enun, E.E., Ijoma, J.U. (2010). Exploring profitability potentials in groundnut production through agroforestry practices: A case study in Nigeria. J. Anim. Plant Sci. 20(2): 123-131.

Binici, S., (2005). The effects of gibberellic acid and abscisic acid on growth physiology and some nutrients uptake in wheat plants grown at high salinity, University of Harran, Graduate School of Natural and Applied Sciences Depertment of Soil Science, Master Thesis, Şanlıurfa, Turkey, pp. 46.

Chauhan, M.P., Singh, I.S. (2000). Variability estimates and identifying chickpea genotypes for yield and yield attributes in salt affected soil. Legumes Research. 23: 199-200.

Duncan, D.B. (1955). Multiple range and multiple F-test. Biometrics. 11: $1-5$.

Durmus, E., Çakaloğulları, U., Tatar, Ö. (2017). Relations between water use efficiency and related physiological parameters of maize in field conditions. The Journal of Agricultural Faculty of Ege University. 52(3): 307-315. ISSN 1018-8851.

FAO (2019). Crop Production Statistics from http://faostat.org/site/ 567/DesktopDefault.aspx? Page ID=56712/06/2008.

Flexas, J., Bota, J., Loreto, F., Cornic, G., Sharkey, T.D. (2004). Diffusive and metabolic limitations to photosynthesis under drought and salinity in C3 plants. Plant Biology. 6: 1-11.

Gadallah, M.A.A. (1999). Effects of proline and glycinebetaine on Vicia faba responses to salt stress. Biologia Plantarum. 42: 249-257.

Gehlot, H.S., Purohit, A. and Shekhawat, N.S. (2005). Metabolic changes and protein patterns associated with adaptation to salinity in sesamum indicum cultivars. Journal of Cell and Molecular Biology. 4: 31-39. 
Ghosh, C.S., Asanuma, K., Kusutani, A. and Toyota, M. (2001). Effect of salt stres on some chemical components and yield of potato. Soil Sci. Plant Nutr. 47(3): 467-475.

Gupta, R., Chakrabarty, S.K. (2013). Gibberellic acid in plant: Still a mystery unresolved. Plant Signal Behav. 8: e25504.

Hassan, M. and İsmail, B.S. (2018). Effect of gibberellic acid on the growth and yield of groundnut (Arachis hypogaea L.). Sains Malaysiana. 47(2): 221-225. http://dx.doi.org/ 10.17576/jsm-2018-4702-02.

Hayat, S., Ahmad, A., Mobin, M., Fariduddin, Q. and Azam, Z.M. (2001). The level of carbonic anhydrase, photosynthesis and seed yield in mustard plants, treated with phytohormones. Photosynthetica. 39: 111-114.

Iba, K. (2002). Acclımatıve response to temparature stres In hıgher plants: Approaches of gene engineering for temparature tolerance. Annu. Rev. Plant Biol. 53: 225-245.

Jiao, X., Zhi, W., Liu, G., Zhu, G., Feng, G., Nimir, E.A. (2019). Responses of foreign GA3 application on seedling growth of castor bean (Ricinus communis L.) under salinity stress conditions. Agronomy. 9: 274.

Khan, M.N., Siddiqui, M.H., Mohammad, F., Naeem, M., Khan, M.M.A. (2010) Calcium chloride and gibberellic acid protect linseed (Linum usitatissimum L.) from $\mathrm{NaCl}$ stress by inducing antioxidative defence system and osmoprotectant accumulation. Acta Physiol. Plant 32(1): 121-132.

Knipp, G. and Honermeier, B. (2006). Effect of water stres on proline accumulation of genetically modified potatoes (Solanum tuberosum L.) generating fructans. Journal of Plant Physiolog. 163: 392-397.

Koca, H. (2007). Effects of salt stress on physiological and biochemical characteristics of different sesamum cultivars, Intitutue of Science, Ph.D thesis, İzmir, Turkey. pp. 132.

Köşkeroğlu, S. (2006). The investigation on accumulation levels of proline and stress parameters of the maize (Zea mays L.) plant under salinity, Intitutue of Science and Technology, Master Thesis, Muğla, Turkey, pp. 120.

Leubner-Metzger, G. (2001). Brassinosteroids and gibberellins promote tobacco seed germination by distinct pathways. Planta. 213: 758-763.

Mafakheri, A., Siosemardeh, A., Bahramnejad, B., Struik, P., Sohrabi, Y. (2010). Effect of drought stress on yield, proline and chlorophyll contents in three chickpea cultivars. Australian Journal of Crop Science. 4(8): 580-585.

Mensah, J.K., Akomeah, P.A., Ikhajiagbe, B. and Ekpekurede, E.O. (2006). Effects of salinity on germination, growth and yield of five groundnut genotypes. African Journal of Biotechnology. 5(20): 1973-1979.

Mohanty, S.K. and Sahoo, N.C. (2000). Effect of soaking period, seed size and growth regulators on imbibition and germination of seeds of some field crops. Orissa Journal Agriculture Research. 18: 219-227.

Moneruzzaman, K.M., Hossain, A.B.M.S., Normaniza, O. and Amru, B.N. (2011). Growth, yield and quality responses to gibberellic acid (GA3) of wax apple Syzygium samarangense var. Jambu air madu fruit grown under field conditions. African Journal of Biotechnology. 10(56): 11911-11918.
Meera, S., Poonam, S. (2010). Response of growth regulators on some physiological traits and yield of chickpea (Cicer arietinum). Progressive Agriculture. 10(2): 387-388.

Öncel, İ., ve Keleş, Y. (2002). Changes of growth, chlorophyll content and solute composition in wheat genotypes under salt stress. University of Çukurova, Faculty of Arts and Sciences. Journal of Science. 23(2): 8-16.

Özcan, H., Turan, M. A., Koç, Ö., Çıkılı, Y. and Taban, S. (2000). Growth and variations in proline, sodium, chloride, phosphorus and potassium concentrations of chickpea (Cicer arietinum L. Cvs.) varieties under salinity stress. Tr. J. of Agriculture and Forestry. 24: 649-654.

Purohit Harsh, B., Patel Riddhi, S., Talavia, B.P. and Kandoliya, U.K. (2020). Effect of gibberellic acid, potassium nitrate and silicic acid on antioxidative enzymes in groundnut (Arachis hypogaea L.) seedling irrigated with saline water. Journal of Pharmacognosy and Phytochemistry. 9(4): 1867-1873.

Renugadevi, J. and Vijayageetha, V. (2006). Organic seed fortification in cluster bean [Cyamopsis tetragonoloba (L.) Taub]. International Conference on Indigenous Vegetables and Legumes. Prospectus for Fighting Poverty, Hunger and Malnutrition. 752: 335-337.

Sayari, A. H., Bouzid, R. G., Bidani, A., Jaoua, L., Savoure, A. and Jaoua, L. (2005). Overexpression of $\Delta 1$ - Pyrroline-5Carboxylate Synthetase increases proline production and confers salt tolerance in transgenic potato plants. Plant Science. 169: 746-752.

Tatar, M.Ö. (2006). Effects of salinity on germination and seedling stage of some rice genotypes University of Ege, Graduate School of Natural and Applied Sciences, Master Thesis, İzmir, Turkey. pp 78.

Teıxeıra, J. and Pereıra, S. (2007). High salinity and drought act on an organ-dependent manner on potato glutamine synthetase expression and accumulation. Environmental and Experimental Botany. 60: 121-126.

Tipırdamaz, R. (1989). The effect of salt and water stress on proportional water content and organic (proline betaine) and inorganic matter $(\mathrm{Na}+, \mathrm{K}+, \mathrm{C} 1-)$ changes in two cultivars of wheat (Triticum aestivum L.) grown in Turkey. University of Hacettepe, Graduate School of Natural and Applied Sciences, Ph.D Thesis, Ankara, pp 124.

Verma, A., Malik, C.P., Sinsinwar, Y.K. Gupta,V.K. (2009). Yield parameters responses in a spreading (cv.M-13) and semispreading (cv.Girnar-2) types of groundnut to six growth regulators. American-Eurasian Journal of Agricultural and Environmental Science. 6(1): 88-91.

Yakıt, S., ve Tuna, A.L. (2006). Effects of $\mathrm{Ca}, \mathrm{Mg}$ and $\mathrm{K}$ on stress parameters in corn plant (Zea mays L.) under salt stress. University of Akdeniz, Journal of the Faculty of Agriculture. 19(1): 59-67. 